\title{
Does Perceived Social Responsibility Affect Consumer Attitudes towards Global Brands? Lessons from Nescafé Case in Turkey
}

Ediz Edip Akcay, (Corresponding author), is a Lecturer in Digital Marketing at Bournemouth University. His research interests are in branding, services marketing, and marketing ethics.

Email: eakcay@bournemouth.ac.uk

Dr Kaouther Kooli, is a Principal lecturer in Marketing at Bournemouth University. Her research interests are in international marketing, consumer behaviour and Business to Business Marketing. Email: kkooli@bournemouth.ac.uk

Dr Hazem Rasheed Gaber, is a Lecturer in Marketing at Arab Academy for Science, Technology and Maritime Transport in Egypt. Much of his research focuses on branding, social media marketing, consumer behaviour and corporate social responsibility.

Email: hazem.rasheed@aast.edu 


\begin{abstract}
This study builds on consumer culture theory, signalling theory and associative network memory model to investigate the impact of consumers' perceptions of global brands' social responsibility on consumers' attitudes towards brands. A survey is implemented in Turkey using Nescafé as an example of global brands. Data from 243 fully completed questionnaires were analysed using SmartPLS. The results from the structural equation modelling indicate that for Turkish consumers the perceived globalness of the brand contributes to the brand's perceived credibility but has a negative direct relationship on the perception of the brand's social responsibility. In addition, the local icon value of the brand has positive and significant relationships with the brand's perceived credibility and the brand's perceived social responsibility. This later has a positive relationship on consumers' attitudes towards the brand. The perceived globalness of the brand is important to develop the perceived credibility of the brand. The paper provides some guidelines for global brands when communicating their social responsibility activities to consumers in emerging markets.
\end{abstract}

Keywords: Global brand, Social responsibility, Attitude towards global brand, Perceived globalness, Global brand credibility. 


\section{Introduction}

The global-local dilemma facing global firms has been the focus of several studies (de Mooij, 2018; De Lima and De Faria, 2018). These firms need to make a strategic decision on whether they should adapt their branding strategy to attract local consumers or develop global brands for growth scope and profit margin potential (Steemkamp, 2017; Gray, 2002). The milestone article of Levitt (1983) about globalisation of markets prompted global firms' endeavour to globalise their brands in their pursuit for cost savings and economies of scale benefits (Keller et al., 2011). Some of the firms such as Coca-Cola or Nescafé use standardised brands in all markets while some choose to adapt their brands like Unilever's various brands in different markets for the same product (Kapferer, 2012). Brand names are used to deliver signals to the consumers about the unobservable information about the products (Rao et al., 1999). The signals are not only about the quality of the product (Rao et al., 1999) but also about the other brand dimensions such as

credibility (Erdem and Swait, 2004), social responsibility (Holt et al., 2004) and globalness (Ozsomer and Altaras, 2008).

In economic, cultural and psychological domains, global brands are increasing their power and influence (Ozsomer, 2012). Yet, the firms are not sure about the exact meanings of their brands' globalness in the eyes of consumers (Dimofte et al., 2008). Understanding how consumers perceive global brands has been the focus of practitioners and academics (Ozsomer et al., 2012; Nie \& Wang, 2019). In addition, global firms need to develop branding strategies to generate the maximum benefits of brand globalness (Kapferer, 2012). However, perceptions about the brands can differ between countries and consumers. To develop their international activities, global firms have to understand the factors that influence consumers' attitude towards their brands (Srivastava and Balaji, 2018).

Since the 90s, global brands' activities are being increasingly scrutinised by activists claiming that their activities are damaging the social and ecological environment in developing countries (Veltmeyer, 2017). Consequently, international drivers for sustainability and social responsibility e.g. United Nations Sustainable Development Goals (SDGs), has created additional challenges for global firms in their quest for international markets. Moreover, Guo et al. (2017) claimed that consumers have stronger willingness to punish irresponsible firms. Hence, marketers need to 
understand consumers' perceptions of global brands' social responsibility and carefully design the marketing strategies for their global brands.

In this regard, some insights could be derived from Krishnan (1996) claiming that consumers develop brand associations - i.e. brand attributes and benefits as well as consumer's experiences with the brand- as indicators of the brand strength. In addition, other studies investigated the factors influencing consumer perceptions of global brands. For instance, Till and Novak (2000) claimed that firms are developing relationships between their brands and social and environmental causes and integrating such relationships in their marketing mix by using associative learning principles as a framework. Also, Strizhakova et al. (2008) investigated the associations between beliefs about global brands and the importance consumers attach to branded products in emerging economies. The authors claimed that brands are passports "to global citizenship" - a person's perception that global brands create an imagined global identity. Furthermore, brands are also considered as symbolic forms that help to develop transnational imagination by facilitating new types of social communication in their brand communities (Cayla and Eckhardt 2008) Corporate social responsibility (CSR) positively influences global brand value (Melo \& Galan, 2011) and global brand equity (Hossain et al., 2019; Hur et al., 2014; Sharma \& Jain, 2019; Torres et al., 2012). Global brand social responsibility is one of the most important factors that influences consumers' attitude towards the brand (Holt et al., 2004). In addition, consumers expect global brands to show social responsibility towards the environment, employees, and other stakeholders they interact with (Holt et al., 2004; Jones, 2005).

Furthermore, firms decide to position their brands as global because of expected consumer choice towards global brands instead of similar local alternatives (He \& Wang, 2017). Kapferer (2012) argued that in order to obtain the most of the expected benefits from globalisation, global firms should develop several brand globalisation strategies in each market. However, Ozsomer and Altaras (2008) added that cultural capital and authenticity of the global brand are also important influencers of the perceptions of the global brands.

To inform brands' globalisation strategies, it is critical to investigate the factors influencing consumers' perceptions and attitude towards global brands (Steenkamp, 2017; Steenkamp et al., 2003). Furthermore, brands are considered as networks of associations rather than monodimensional effects (Özsomer \& Altaras, 2008). Hence, it is important to understand consumer 
perceptions and associations of brands in order to understand how consumers make their choices (Henderson et al., 1998). Therefore, this study builds on consumer culture theory (Arnould \& Thompson, 2005; Özsomer \& Altaras, 2008), signalling theory (Batra et al., 2000; Rao et al., 1999) and the associative network memory model (Krishnan, 1996; Till \& Nowak, 2000) to investigate the influence consumers' perceptions of global brands' social responsibility on their attitude towards the brand. This study aims to identify the antecedents of consumers' perceptions of global brands' social responsibility. It also examines the impact of these perceptions on consumers' attitudes towards the global brands in local markets.

The article is organized as follows. First, an overview of the concept of global branding is presented as well as its theoretical underpinnings. This is followed by a discussion on the research hypotheses and a presentation of the proposed conceptual model. Second, the methodology that was adopted is presented, followed by a presentation of the findings. Finally, a discussion of the theoretical and managerial implications will be provided together with the research limitations and directions for future research. 


\section{Literature review}

A brand is "a name, term, design, symbol, or any feature that identifies one seller's good or service as distinct from those of other sellers" by The American Marketing Association (AMA, 2014). Keller (2011) stated that brands have tangible dimensions (e.g. product performance) and intangible dimensions reflect i.e. what a brand represents, and both contribute to create awareness, reputation and prominence among consumers by providing clues to distinguish the seller's products from others. In addition, the author emphasised that brands create networks of associations in the mind of consumers and influence their purchasing and decision process. Marketing communications and advertising are critical to direct those associations about the brand (De Mooij, 2018).

Moreover, brands reflect firms' visibility and position in international markets (Douglas et al., 2001). Firms need to spread their brands geographically for growth, innovation ability and competitive sustainability regarding economies of scale and productivity (Kapferer, 2012). They should build a consistent global brand structure in order to introduce strong brands into new markets, enhance brand portfolio with acquired brands and integrate their strategies across markets (Douglas et al., 2001).

Developing global brands to exploit new markets became a pathway of growth for organisations. Thus, firms should manage their operations as if the world is one large market whilst ignoring regional and national differences (Levitt, 1983). Buzzell (1968) emphasised that global firms should standardise their products and marketing programs because of the expected cost savings and image consistency between markets. Levitt (1983) reinforced that global firms should standardise their products across countries in order to benefit from economies of scale and this is due to the improvements in technology, transportation and communication that led to similar segments and consumer needs. Although Levitt was mostly concerned about global products, his article initiated great interest in global branding (Rosen et al., 1989).

The idea of brand globalisation became particularly popular in the 1980s and 90s after the liberalisation of new country markets for foreign competition. Several American and Japanese firms introduced their global brands and marketing programs into those markets (Holt et al., 2004). Factors including the emergence of global media, the Internet, mobile communications, improvements in production techniques in both developed and developing countries accelerated 
the global market integration (Ozsomer et al., 2012). Conversely, Hollis and Fitch (2009) question the advantages of global branding because of the increasing diversity and complexity in the world despite the technological developments. They claim that local brands that operate in one country or in a limited region (Schuiling and Kapferer, 2004) have many advantages, such as their closeness to local culture and closer ties with consumers than global brands.

There are various definitions of global brands from the customer and company perspective. Although there might be slight variations in the marketing mix, a global brand is defined as a brand sold in most countries in the world and applies equivalent strategic principles, positioning, and marketing in all markets worldwide (Johansson, 2010). With the same brand or logo, it dominates markets with a significant market share and brand loyalty (De Mooij, 2018). The research company Nielsen defines global brands as brands selling in all four economic regions of the world with at least 5 percent of its revenue outside its home region (Mitchell, 2002). Interestingly, consumer's perception of the brand's globalness also characterises the global brand in the markets they operate (Ozsomer and Altaras, 2008). According to this view, a firm can position its brand as global in the consumer's perception even if the brand does not meet the criteria of being global, such as the number of countries they operate in.

Understanding consumers' perception of global brands is a key factor that enables firms to position their brands (Ozsomer and Altaras, 2008). In addition, consumers in different countries may respond differently to marketing mix elements (Keller et al., 2011). Hollis and Fitch (2009) added that different consumer needs and expectations in different cultures might decrease the expected scale advantage of a global brand if the brand and marketing communication are customised. However, because of the misinterpretation of global integration, global firms' subsidiaries might overly standardise or localise the marketing communication (Ozsomer and Simonin, 2004). In order to find the right balance, practitioners are trying to evaluate how consumers purchase products, what they know and feel about brands (Keller et al., 2011). Hence, it is important to mix global objectives with local or regional concerns to develop global customer-based brand equity with brand awareness and a positive brand image in each country (Keller et al., 2011).

\section{Culture, signalling theory, associative network memory model and global Brands}

There has been a growing interest among scholars to examine the impact of culture on global marketing and advertising (Steenkamp, 2019; De Mooij and Hofstede, 2010). Global consumer 
culture has an increasing influence in the marketplace which has led to dramatic changes in the local consumer culture (Steenkamp, 2019). Global brands face important challenges hindering their effort to ensure the consistency of concepts across markets and consumers from different cultures (Torelli et al., 2012). Hofstede (cited in De Mooij, 2018) claims that consumer behaviour is the unique aspect of the business that is culture dependent. In addition, the existence of global products does not prove the existence of global people (de Mooij, 2018) and business success is dependent on how well the products reach consumers who have various behaviours. Firms should consider cultural terms to find out how consumers perceive their global brands (Holt et al., 2004). Global-local dilemma, that is standardising marketing and advertising for efficiency reasons or adapting to local habits and consumer intentions for effectiveness, is the source of growing interest about the influences of culture (De Mooij and Hofstede, 2010). However, the main debate should be about the effectiveness of cultural segmentation rather than the efficiency of standardisation (De Mooij, 2018). The customers can be segmented into global, "glocal”, local and alienated groups across countries according to their attitudes and identity beliefs (Ozsomer et al., 2012, p.3).

The growth of global consumer segments (Hassan et al., 2003) has led to the prominence of global consumer cultures and common symbols for the segments such as product categories, consumption activities and brands (Alden et al., 2006). Global firms try to build a consistent brand image across countries by global standardised communication. Also, consumers from different cultures might perceive the same brand in completely different ways (de Mooij, 2018).

Schuiling and Lambin (2003) claimed that even though global brands aim to benefit from a unique brand image, there are important differences in the image perception between the country of origin and other consumers in other countries. The authors conducted a study involving 347 global brands and highlighted that global brands are perceived as higher quality, more trustworthy and better value in their home country. Bengtsson et al. (2010) support the impacts of cultural context by showing divergent brand meanings of standardised global brand platforms in different countries. Recent studies (Taylor and Okazaki, 2015; Liu et al., 2017) about the influences of culture on global marketing and advertising indicated the necessity of adjusting branding and advertising strategies to the culture of the consumer. The studies that included financial performance criteria showed that an adaptation strategy is more effective (de Mooij and Hofstede, 2010). 
Moreover, the signalling theory (Rao et al., 1999) suggested that brand names are used to deliver signals to consumers about the unobservable information about the products such as the credibility of the brand (Erdem and Swait, 2004), social responsibility of the brand (Holt et al., 2004) and globalness of the brand (Ozsomer and Altaras, 2008). For instance, Till and Novak (2000) claimed that firms are developing relationships between their brands and social and environmental causes and integrating such relationships in their marketing mix by using associative learning principles as a framework. Also, Strizhakova et al. (2008) investigated the associations between beliefs about global brands and the importance that consumers in emerging economies attach to branded products.

Besides, the associative network memory model considers "individuals' memory as a network of interconnected nodes that activate each other in relevant contexts" (Anderson and Bower, 1973 cited in Teichert and Shontag, 2010, p.371). In this line, Keller (1993) suggested that individual form brand associations, which are considered as informational nodes e.g. Visual stimuli in consumer memory linked to the brand and that grasp the brand sense as understood by the consumer. Krishnan (1996) also claimed that consumers develop brand associations - i.e. brand attributes and benefits as well as consumer's experiences with the brand- as indicators of the brand strength.

Consumer behaviour as well as the global drivers of social responsibility i.e. UNSDGs stress the need to further investigate the relationship between global brand social responsibility and consumer attitude. There is a little empirical evidence about this relationship especially in the context of emerging markets. For instance, Srivastava et al. (2020) highlighted the influence of perceived brand globalness, localness and authenticity on brand credibility in the Indian market. However, the authors emphasised the need to further investigate the influence of brand credibility and its determinants on different aspects of brand attitude in other emerging markets (Srivastava et al., 2020). Building on consumer culture theory, signalling theory and associative network memory model, this study suggests further understanding the influence of perceived social responsibility on consumer attitude towards global brands in emerging markets taking the example of Turkey. 


\section{Patterns of Brand Globalisation}

Interbrand, the global brands consultancy, publishes the best global brands list annually based on its methodology to calculate brand value (Interbrand, 2018). Their list improved the interest in global brands in the last decade, putting global brands like Coca Cola, Microsoft, Google, Amazon, Apple, McDonald's at the centre of attention. Most of the global brands in that list feature robust sales both in their domestic markets and in other regions of the world (Quelch and Deshpande, 2004). Those famous global brands are perceived as the symbols of globalised lifestyle on one side and the threats for local competition on the other side (Riefler, 2012). They have benefited from the globalisation of the markets during the 1990s through increasing consumers' attraction towards Western brands (Riefler, 2012).With the changing market conditions, the successful global brands capture market share from other global brands while local brands prosper by responding to local tastes and needs. As a globalisation strategy, international firms usually add successful local brands to their brand portfolios to attract different consumer segments (Quelch and Deshpande, 2004).

Kapferer (2012) argued that some global firms choose to use the same product platform and endorse the local brands for each market. The firm can use the same brand for all countries and adapt the products according to local tastes. For example, Nescafé has a standardised brand name in the markets where it operates, but also, adapted its products range according to consumer tastes in different countries. For example, the company has a single-serve coffee product "Nescafé 3 u1 arada" in Turkey (Nestle Turkiye 2019a) while it has "Nescafé Dolce Gusto" product range for United Kingdom market to serve shop quality coffee at home (Dolce Gusto 2012). Unilever is a Global fast-moving consumer goods (FMCG) producer that follows a similar strategy for their brands portfolio (Kapferer, 2012). Unilever uses a production platform and use local or regional brand names in different markets for the same products. Unilever has four basic product platforms for their ice-cream business in Europe; however, the local brand names are maintained: Same product range is sold under Wall's brand in the United Kingdom whereas the main brand in Turkey is Algida (Kapferer, 2012).

Alashban et al. (2002) claimed that standardising the brand name can lead to higher cost savings and the degree of adaptation for brand names is related to the competition intensity, buyer and distribution factors of market structure. Another example i.e. Procter \& Gamble (P\&G), one of the biggest global firms, moved towards marketing standardisation of its global brands in the late 90s 
which was soon followed by its rival Unilever (Ozsomer et al., 2012). Similar to P\&G, Unilever changed its strategy to focus on building strong multiple global brands (Torres et al., 2012). Global firms can build excellent global brands if they facilitate the involvement of best practices across countries, support a shared global-brand planning process and allocate brand responsibility between markets for synergies against local bias (Aaker and Joachimsthaler, 1999).

\section{Brand Globalness, credibility and social responsibility}

Holt et al. (2004) conducted a study using top 100 global brands present in twelve countries and claimed that global brands are expected by consumers in those countries to behave responsibly. This hypothesis was also discussed by Ozsomer and Altaras (2008) without any empirical investigation. A study conducted in Vietnamese fast food industry (Vuong and Giao, 2020) reinforced that perceived brand globalness (Starbucks, McDonalds and KFC) positively influence perceived social responsibility. The authors also claimed that perceived brand globalness positively influences the brand credibility. Such findings were also corroborated by Mandler et al. (2020) conducted two studies in Germany and South Korea- taking the example of fast food restaurants, automobile and sweets-, and highlighted that perceived brand globalness positively influence brand credibility, because its worldwide availability is a strong signal of expertise and trustworthiness of the brand. Hence, the following hypotheses are posited:

H1: Perceived brand globalness positively influences global brand credibility.

H2: Perceived brand globalness positively influences the perception of global brand social responsibility.

\section{Global Brand Cultural Capital, Authenticity and Local Icon Value}

According to consumer culture theory, the cultural capital perceived in global brands is one of the resources used by consumers to build their identities (Ozsomer and Altaras, 2008). Ger (1999) added that cultural capital is a source of competitive advantage for local firms that they can utilise to compete with Global firms. The author defines cultural capital as a "special form of resource, a proficiency in the consumption of and the discourse about prestigious cultural goods" (Ger, 1999, p.69). Hence, by developing local strategies based on quality and authenticity, local brands can have a competitive success in the global market with their unique perceived value, cultural capital and alternative targeting and positioning (Ger, 1999). In this line, Yotova (2018) conducted a study 
in Japan taking the example of foreign food brands and found that traditionalizing the image of industrial food products could improve the perceptions of the brands by signalling authenticity of brand. The author refers to Bulgarian Yogurt sold in Japan to emphasise how this product is loaded with localness, mastership and tradition.

Kapferer (2012) interestingly argued that global brands that want to access a wide public across countries can also try to be perceived as "local" in those countries in order to be close to consumers. For example, for its Turkish market, Lays, a brand owned by PepsiCo, featured a woman wearing a traditional Turkish outfit and speaking the local dialect in its advertising campaign and as a result the brand increased its sales by 5 times (Hurriyet, 2006). However, Kapferer (2012) adds that "high-tech" brands such as IT products, luxury goods and top-class cosmetics do not follow this trend in order for it to not be perceived as "local and low-tech".

Batra et al. (2000) added that marketplace mythologies, narratives, and places of origin can be used as associations for global brands to create their cultural capital for the global, foreign or local consumer culture. This is also in line with Holt et al. (2004) claiming that consumers accept global brands as symbols of cultural ideals because of their cultural myths with global appeal. Holt et al. (2004) found that "global myth" is one of the significant dimensions of global brands that explain consumer's global brand preference over local brands.

The positive effect of perception about being an icon of the local culture on purchase likelihood is shown in the studies of Steenkamp et al. (2003) and Ozsomer (2012). Steenkamp et al. (2003) claimed that global brands can benefit from Ger's (1999) cultural capital concept if they succeed to be perceived as an icon of the local culture in the countries where they operate. Ger (1999) also emphasized that local icon value is an expression of authenticity.

Therefore, a brand that is a symbol of local culture can also be perceived as global at the same time. While being perceived as global, local symbols can be blended into marketing programs by global brands to benefit from this positive effect (Alden et al., 2006). Ozsomer and Altaras (2008) assume that the global brands which could create the right type of cultural capital (local, foreign or global) will generate perceptions of authenticity.

Ozsomer and Altaras (2008) claimed that the perceived authenticity of a global brand positively influences consumers' perception of its social responsibility. In addition, A number of studies showed that brands increase their credibility after proving their international appeal to consumers 
(Roy and Chau, 2011; Erdem and Swait, 2004; Steenkamp et al., 2003). Holt et al. (2004) added "global myth" and social responsibility dimensions as determinants of global brand preference. Mandler et al. (2020) and Erdem and Swait, (1998) also claimed that global brands signal their ability and willingness to deliver what they promise and in doing so they increase consumer perceptions of their credibility in the local market context

From the previous discussion, the following hypotheses are stated:

H3: Global brand local icon value positively influences global brand credibility

H4: Global brand local icon value positively influences the perception of global brand social responsibility.

\section{Consumers' attitude towards global brands and perceived social responsibility}

Globalisation increased the number of both foreign and local brands that consumers can choose from (Hsieh, 2002). The physical qualities, packaging, price, advertising and promotion influence the consumer's perception about any brand (Munn, 1960). A worldwide sold brand with all global brand characteristics might not be perceived as global by consumers in every country (De Mooij, 2018) and consumers from different markets might perceive brands differently, which will in turn, influence their choice and purchasing behavior (Hsieh, 2002). Firms decide to position their brands as global because of expected consumer choice towards global brands instead of similar local alternatives. Accordingly, it is necessary to investigate the motives behind consumer's perception and attitude towards global brands (Steenkamp et al., 2003). Several studies show the underlying reasons for consumer's attitude and preference toward global brands. In addition, the importance of global brand dimensions, including perceived social responsibility, on consumer attitude can change between culturally and economically different countries (Erdem et al., 2006).

Global brands are expected to behave in a socially responsible manner in the markets they operate (Ozsomer et al., 2012). The aforementioned research by Holt et al. (2004) investigated consumers in 12 countries to find out why consumers choose global brands over local brands. The authors identified the significant dimensions influencing consumer preference for global brands and emphasised the increasing importance of corporate social responsibility. Consumers not only in developed but also in developing markets expect global brands to behave responsibly towards social issues (Holt et al., 2004). Jones (2005) added that global brands' social responsibility 
influences brand preference. The author further explained that brand equity and value are not only built between the brand and the consumer but also supported by the sum of firm's relationships with all stakeholders, and most importantly, the synergy between brand's different relationships with employees, NGOs, suppliers, media increases the brand value. These relationships reflect the brand's social, ethical and environmental responsible behaviours to consumers (Jones, 2005).

Melo and Galan (2011) also investigated the influence of corporate social responsibility on brand value using data from Interbrand "Most Valuable Brands" report. The authors claimed that corporate social responsibility has more effect on brand value than other market-based performance indicators. Social responsibility initiatives such as employee empowerment practices, energy-saving programmes would help firms to increase their brand value (Melo and Galan, 2011). Similarly, Torres et al. (2012) showed the positive effect of corporate social responsibility on global brand equity and consumer preferences. Moreover, perceived social responsibility of global brands has an impact on brands image and consumer attitudes towards those brands ( $\mathrm{Wu}$ and Wang, 2014). However, Ozsomer and Altaras (2008) argued that global brands need to improve their credibility in order to develop consumers' perception of their social responsibility and attitude towards them. The authors recommended to empirically test such claims in future research endeavours. Therefore, the following hypotheses are stated:

H5: Global brand credibility positively influences the perception of global brand social responsibility.

H6: Perception of the global brand social responsibility influences the attitude towards the global brand

Figure 1: Research Framework 


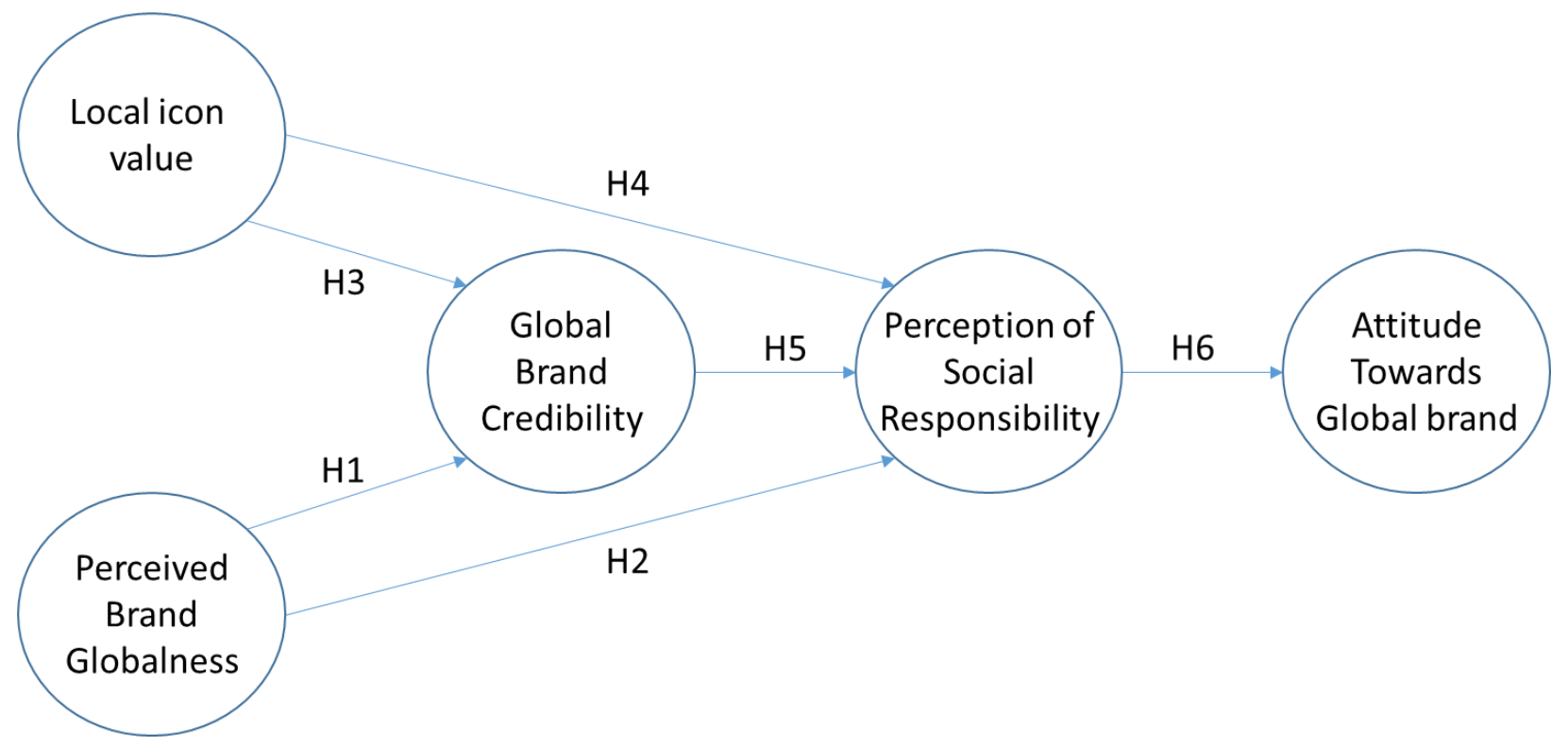

\section{Research Methods}

This article depended on a quantitative research approach (Bell et al., 2018). An online survey was used to collect data from consumers in Turkey. This form of surveys is considered faster and cheaper relatively to other survey methods (Malhotra \& Dash, 2016). It has the advantage of being highly targeted, since the researcher retains control over who is allowed to participate in the survey (Sue \& Ritter, 2012). Also, respondents answering online surveys feel a high degree of anonymity, which makes them express their views more openly (Blumberg et al., 2014).

Since the target of the online survey is Turkish consumers, who are familiar with global brands, the hyperlink of the online questionnaire was posted on several social media platforms e.g. Facebook, Twitter and LinkedIn to include a diversity of participants. After several months of multiple postings, 243 complete responses were collected.

The survey is developed based on an extensive literature review and previously validated measurements are adopted. Appendix 3 shows the questionnaire items in both English and Turkish. The local iconic value of the global brand is measured using three items adapted from Steenkamp et al. (2003). Brand credibility is measured using four items related to the brand's expertise and trustworthiness (Erdem and Swait, 2004). To measure perceived social responsibility of the global brand, five items are adapted from Holt et al. (2004). Perceived brand globalness is measured using the scale of Steenkamp et al. (2003) and supported by questions from several articles (Sweeney and Soutar, 2001; Baek et al., 2010; Erdem et al., 2006). The attitude towards global brand is 
measured using a scale validated by Batra et al. (2000) and Park et al. (2010). In addition to the questions that captured the study's constructs, the survey also included some questions about the age group, gender, educational background, occupation, income level and place of residence of the respondents. The questionnaire, originally developed in English, was translated to Turkish language to be more convenient for the study's population. After that, it was back translated to English to ensure the accuracy of the translation (Maneesriwongul \& Dixon, 2004).

\section{Choice of the global brand}

Since the purpose of this article is to investigate consumers' perceptions towards global brands in Turkey, Nescafé is chosen as an example of global brands to be tested because of its long history and market leadership in Turkey. Instant coffee product category is chosen as a low involvement and hedonic product according to Ratchford (1987) dimensions which classify products regarding their involvement and utility/hedonic levels. Using a hedonic product as a global brand example is relevant considering the high aspiration values both global brands and hedonic products have (Ozsomer, 2012). Coffee is one of the most popular and global goods in the world which is the world's most consumed drink after water and most traded commodity after oil (Nestle Turkiye, 2019a). Nescafé is the first instant coffee brand in Turkish market when it was introduced in 1984 (Nestle Turkiye, 2019b). The brand even became the generic name of instant coffee in Turkey thanks to its popularity (Kahve Cini, 2010).

\section{Results}

The data is analysed using partial least square structural equation modeling (PLS-SEM) (Hair et al., 2019) with SmartPLS 3.0. The PLS-SEM method was the most appropriate, considering the nature and sample size of this study (Hair et al., 2019). In PLS-SEM, model evaluations use Rsquare values for the dependent constructs and the effect size, significance level, and t-values of the structural path coefficients (Fornell \& Cha, 1994). The estimates of standard errors and t-values came from a bootstrap resampling procedure (Chin, 2001). 


\section{Measurement validation (Appendix 1)}

To conduct the structural equation modelling, firstly it is important to check unidimensionality of each construct in the model (Hair et al., 1998) which could be verified using Cronbach's alpha $(\alpha)$ and composite reliability (CR) values that should be larger than 0.7 (Tenenhaus et al., 2005). The Cronbach's $\alpha$ values vary from 0.749 to 0.869 and the CR values vary from 0.874 to 0.920 , which are above 0.7 (Table 1). The outer weights, outer loadings, and average variance extracted (AVE) measures are also presented in Table 1. Individual item reliability can be assessed through "the outer loadings, which represent the loadings of the reflective manifest variables with their respective latent variables" (Mustapha \& Hassan, 2017, p. 296). Hulland (1999) suggested to accept any loading greater than 0.7 to assess individual item reliability.

After checking the factor loadings as shown in Table 1, five items were dropped as they had poor item loadings; these items are LIV3, PG2, CRE1, SOC4 and SOC5. All constructs have a variance inflation factor (VIF) values less than 2.1, which is within the cut-off level of 3.0, suggesting the absence of multicollinearity (Hair et al., 2011). The findings show that the average variance extracted (AVE) measures range between 0.699 and 0.806; hence, exceeding the threshold value of 0.5 (Fornell \&Larcker, 1981). In addition, the square root of AVE assessed for each construct in the research model exceeds the correlations of the construct with other constructs (Table 2), and thus, supports the discriminant validity of the measures (Fornell \&Larcker, 1981).

Table 1: The results from the measurement model estimation (weight, loading, CR value, Cronbach's $\alpha$, and AVE).

\begin{tabular}{|c|c|c|c|c|c|c|}
\hline $\begin{array}{c}\text { Latent } \\
\text { variable } \\
\text { Manifest }\end{array}$ & $\begin{array}{l}\text { Manifest } \\
\text { variable }\end{array}$ & $\begin{array}{c}\text { Outer } \\
\text { weight }\end{array}$ & $\begin{array}{c}\text { Outer } \\
\text { loading }\end{array}$ & $\begin{array}{l}\text { Cronbach's } \\
\text { alpha }(\alpha)\end{array}$ & CR value & AVE \\
\hline \multirow{3}{*}{$\begin{array}{l}\text { Local icon } \\
\text { value }\end{array}$} & LIV1 & 0.505 & 0.908 & \multirow[t]{3}{*}{0.760} & \multirow[t]{3}{*}{0.893} & \multirow[t]{3}{*}{0.806} \\
\hline & LIV2 & 0.486 & $\begin{array}{l}0.888 \\
\end{array}$ & & & \\
\hline & LIV3 & 0.300 & 0.496 & & & \\
\hline \multirow{3}{*}{$\begin{array}{l}\text { Perceived } \\
\text { brand } \\
\text { globalness }\end{array}$} & PG1 & 0.268 & 0.801 & \multirow[t]{3}{*}{0.749} & \multirow[t]{3}{*}{0.876} & \multirow[t]{3}{*}{0.781} \\
\hline & PG2 & 0.283 & 0.597 & & & \\
\hline & PG3 & 0.674 & 0.959 & & & \\
\hline \multirow{4}{*}{$\begin{array}{l}\text { Global brand } \\
\text { credibility }\end{array}$} & CRE1 & 0.176 & 0.585 & \multirow[t]{4}{*}{0.783} & \multirow[t]{4}{*}{0.874} & \multirow[t]{4}{*}{0.699} \\
\hline & CRE2 & 0.323 & 0.844 & & & \\
\hline & CRE3 & 0.328 & 0.877 & & & \\
\hline & CRE4 & 0.289 & 0.784 & & & \\
\hline \multirow{3}{*}{$\begin{array}{l}\text { Perception of } \\
\text { Social } \\
\text { Responsibility }\end{array}$} & SOC 1 & 0.346 & 0.870 & \multirow[t]{3}{*}{0804} & \multirow[t]{3}{*}{0.884} & \multirow[t]{3}{*}{0.718} \\
\hline & SOC2 & 0.303 & 0.826 & & & \\
\hline & SOC3 & 0.362 & 0.846 & & & \\
\hline
\end{tabular}




\begin{tabular}{|l|c|c|c|c|c|c|}
\hline & SOC4 & 0.245 & 0.664 & & & \\
\cline { 2 - 4 } & SOC5 & 0.228 & 0.618 & & & \\
\hline \multirow{2}{*}{$\begin{array}{l}\text { Attitude } \\
\text { toward the }\end{array}$ Global Brand } & ATT1 & 0.285 & 0.787 & 0.869 & 0.920 & 0.793 \\
\cline { 2 - 4 } & ATT2 & 0.402 & 0.942 & & & \\
\cline { 2 - 4 } & ATT3 & 0.425 & 0.934 & & & \\
\hline
\end{tabular}

Table 2: Inter-construct correlations and square root of AVE measure

\begin{tabular}{|c|c|c|c|c|c|}
\hline & ATT & CRE & LIV & PG & SOC \\
\hline ATT & 0.891 & & & & \\
\hline CRE & 0.729 & 0.836 & & & \\
\hline LIV & 0.322 & 0.35 & 0.898 & & \\
\hline PG & 0.438 & 0.46 & 0.211 & 0.884 & \\
\hline SOC & 0.647 & 0.674 & 0.334 & 0.213 & 0.847 \\
\hline
\end{tabular}

\section{Structural model and hypothesis testing (Appendix 2)}

After validating the measurement model, the research then estimates the structural model which specifies the relationships between latent variables. See Figure 2 for the path coefficients for the endogenous latent variables together with the R-squares. The empirical results show that global brand local icon value significantly and positively influences global brand credibility ( $\beta=0.265$, $\mathrm{p}=0.0000, \mathrm{t}=5.281$ ), thus $\mathrm{H} 3$ is supported. Additionally, perceived brand globalness positively and significantly influences global brand credibility $(\beta=0.404, \mathrm{p}=0.0000, \mathrm{t}=6.445)$. Therefore, $\mathrm{H} 1$ is supported. The results also show that global brand local icon value significantly and positively influences the perception of global brand social responsibility $(\beta=0.119, p=0.034$, $\mathrm{t}=2.129$ ), thus $\mathrm{H} 4$ is supported. Contrary to our predictions, perceived brand globalness is found to have a significant negative effect on the perception of global brand social responsibility ( $\beta=$ $0.131, \mathrm{p}=0.021, \mathrm{t}=2.313$ ), thus, $\mathrm{H} 2$ is rejected. Furthermore, H5 is supported as it is found that global brand credibility positively and significantly influences the perception of global brand social responsibility $(\beta=0.693, p=0.000, t=13.311)$. Finally, the results confirm the significant and positive relationship between global brand social responsibility and the attitude towards the global brand ( $\beta=0.647, p=0.000, t=15.836$ ), thus, H6 was supported. Table 3 summarizes the results of the hypotheses' testing. 
Table 3: Summary of Hypothesis testing

\begin{tabular}{|l|l|c|c|c|c|}
\hline Hypothesis & Relationship & Coefficient & t-value & p-value & Conclusion \\
\hline H1 & PBG $\rightarrow$ CRE & 0.404 & 6.445 & 0.000 & Supported \\
\hline H2 & PBG $\rightarrow$ SOC & -0.131 & 2.313 & 0.021 & Rejected \\
\hline H3 & LIV $\rightarrow$ CRE & 0.265 & 5.281 & 0.000 & Supported \\
\hline H4 & LIV $\rightarrow$ SOC & 0.119 & 2.129 & 0.034 & Supported \\
\hline H5 & CRE $\rightarrow$ SOC & 0.693 & 13.311 & 0.000 & Supported \\
\hline H6 & SOC $\rightarrow$ ATT & 0.647 & 15.836 & 0.000 & Supported \\
\hline
\end{tabular}

The following figure (Figure 2) shows the standardized path coefficients, $t$ values and coefficients of determination $\left(\mathrm{R}^{2}\right)$ of the latent variables.

Figure 2: Empirical study results

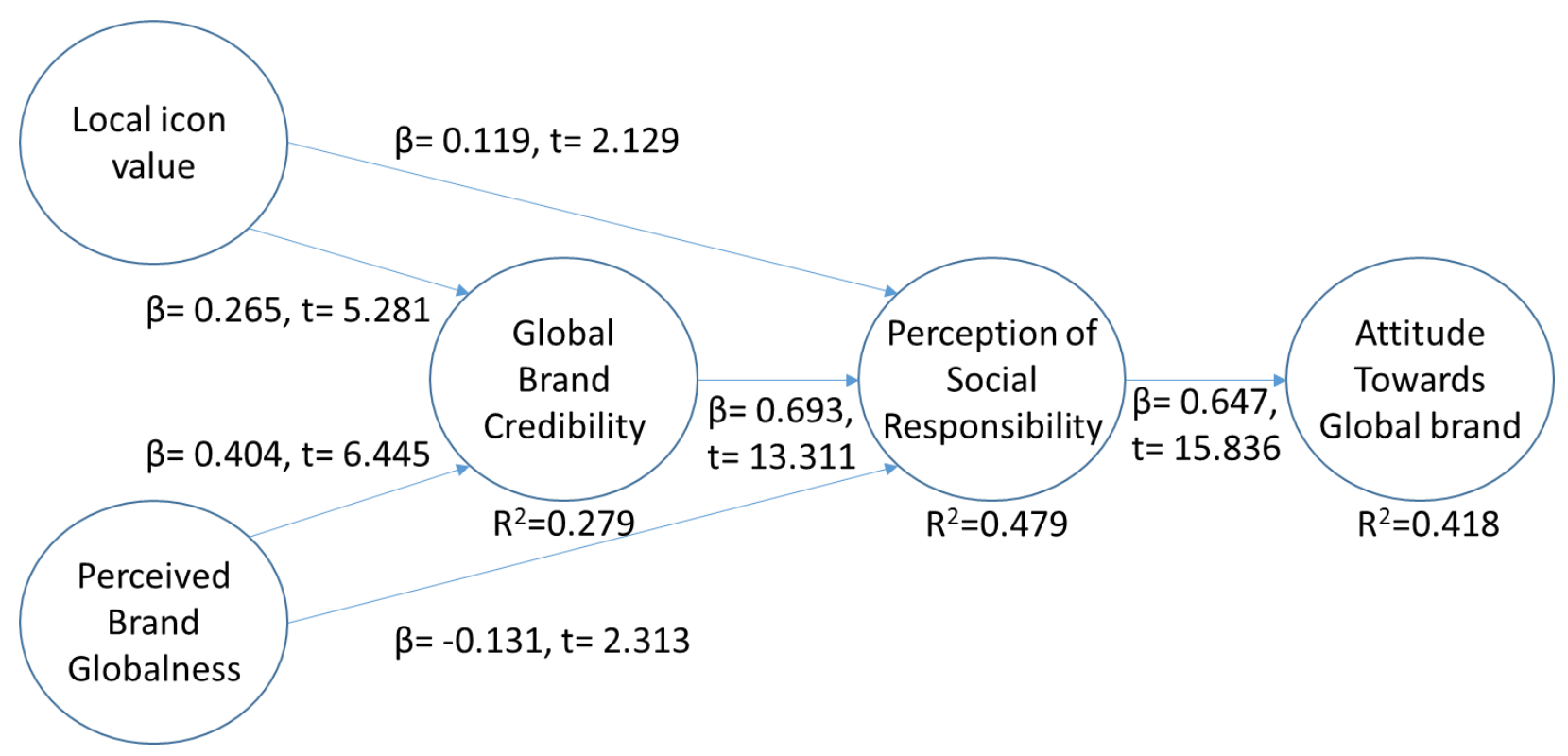

According to the results of the $\mathrm{R}^{2}, 27.9 \%$ of the variance of global brand credibility can be explained by local icon value and perception of brand globalness, $47.9 \%$ of perception of social responsibility can be explained by local icon value, global brand credibility and perception of brand globalness. Finally, $41.8 \%$ of consumers' attitudes towards the global brand can be explained by the perception of social responsibility. 


\section{Discussion}

Local icon value, perceived brand globalness and perceived brand credibility (H1 and H3)

Our findings show that global brand local icon value and perceived brand globalness significantly influence global brand credibility. However, the influence of perceived brand globalness is more important than the influence of local icon value. Perceived brand globalness seems to play a stronger role in generating brand credibility than the local icon value of the brand. These findings are in line with Vuong and Khanh Giao (2020) findings that indicated that consumers in developing countries prefer imported global products as they are perceived to have superior quality and brand prestige. These findings are also similar to Ozsomer and Altaras's (2008) findings showing that consumers usually perceive the brand that is globally available and accepted around the world to be more credible and trustworthy than local brands. Our findings show that it is critical for brands to be positioned as global to enhance their credibility among consumers in Turkey. To achieve this positioning, Erdem and Swait (2004) highlighted the importance of investing in branding in order to develop the global positioning of the brand which consequently increases its credibility. Furthermore, the results support the findings of Mandler et al. (2020) who found out that local icon value and perceived brand globalness are more important signals of brand credibility in emerging markets than the developed markets.

It should be noted that the global brand selected for this study i.e. Nescafe, has a strong local and historical rival which is Turkish coffee (Izberk-Bilgin, 2008). The authors uncovered that Turkish consumers show a resistance to global brands in the coffee category because they consider Coffee global brands as a threat for Turkish coffee. Therefore, it can be suggested that the strong local icon value of Turkish coffee makes it difficult for Nescafe to establish its local presence in its category.

\section{Perceived Brand Globalness and Global brand perceived social responsibility (H2)}

The literature review emphasises a positive relationship between perceived brand globalness and perceived brand social responsibility (Vuong and Khanh Giao, 2020; Ozsomer and Altaras, 2008). However, our results uncovered a negative, but significant, relationship between the two variables. This result indicates that the more Turkish consumers perceive the brand to be global, the less they will perceive the social responsibility of the brand. This result contradicts previous studies claiming that consumers expect global brands to behave socially responsible in the markets they 
operate (Holt et al., 2004; Melo and Galan, 2011). However, in this study, for Turkish consumers, the perception of the globalness of a brand negatively influences the perception of the brand's social responsibility projects. This result could be either because Nescafé did not communicate enough about it social responsibility efforts (Nestle 2019b), hence, it did not create awareness in Turkey, or, social responsibility's efforts were not perceived as being local or relevant for the Turkish market (Keane \& Morschett, 2017). Nestle Turkey's website promotes CSR practices linked to sustainable coffee production in 14 countries other than Turkey (Nestle 2019b). However, the social responsibility projects of Nescafé with regard to sustainable coffee production, do not seem to be relevant for Turkish consumers, thus, it did not lead to positive perception of Nescafé CSR efforts.

In addition, previous studies showed that consumers' animosity towards brands caused by conflicts and negative events has an impact on their attitude towards global brands (Ramadania et al., 2014). This could explain the significant and negative relationship between perceived brand globalness and perceived CSR of the brand. This animosity is exacerbated by recent scandals caused by global brands in Turkey and in the world. For example, Turkish people protested against Alamos Gold which is a Canadian company. Its operations are destroying the natural environment because workers for this company cut trees and use harmful substances that pollute the soil and the water in Ida Mountains (Deutsche Welle, 2019). Similarly, Turkish consumers reacted to the emission scandal caused by Volkswagen (BBC, 2015). Before the scandal it was the most sold car brand in Turkey and the brand lost its leadership in terms of sales after the scandal (Sabah, 2017).

\section{Global brand local brand icon value and perceived social responsibility (H4)}

According to the findings, the local icon value of the global brand is positively related to the perception of the brand social responsibility. These findings are in line with Keane and Morschett (2017) who claim that global brands should localise their CSR activities to influence the consumers' willingness to purchase. In their study, they showed that the brands which localised their CSR activities to the host country will generate higher local consumer willingness to purchase the brand. Thus, the increased local icon value of the brand contributes to positive perception about the brand's CSR and willingness to buy. However, Keane and Morschett's study was conducted in the USA with a focus on foreign retailers. 
Moreover, Riefler (2020) claimed that global brands can mitigate competitive disadvantages by authenticating their brand image. Hence, it can be argued that this will increase the local icon value and as a result, the brand credibility and perceived social responsibility.

Perceived brand credibility and perceived social responsibility (H5)

The results demonstrated that there is a significant positive relationship between the credibility of the global brand the perception of the brand social responsibility. This result is in line with Alcañiz et al. (2010) who found a strong relationship between the two variables in the context of Spanish fast-moving consumer goods. The authors argued that consumers "respond and place greater value on any CSR initiative developed by a socially credible company" (Alcañiz et al. 2010, p:170). Furthermore, de Jong and van der Meer (2017) found that the credibility of the organisation is one

of the key factors in achieving positive CSR outcomes. In addition, this finding contributes to further address Ozsomer and Altaras (2008) claim, the need to empirically validate the impact of credibility on perceived social responsibility.

Perceived global brand Social Responsibility and Attitude towards the Global Brand (H6)

The results emphasise a significant positive relation between global brand perceived social responsibility and consumers' attitudes towards global brands. This means that it is very important that consumers perceive the social responsibility of the brand in order to develop a positive attitude towards the brand (Ferrell et al., 2019). These results are in line with previous studies emphasising that consumers expect global brands to be socially responsible (Holt et al., 2004, Melo and Galan, 2010). Turkish consumers expect the global brand Nescafé to be socially responsible in order to develop a positive attitude towards it.

\section{Contribution and Managerial Implications}

The purpose of the paper is to investigate consumers' perceptions of global brands' social responsibility and the influence of these perceptions on consumers' attitudes towards those brands. Past studies separately tested the influences of several global brand dimensions derived from consumer culture theory, signalling theory and associative network memory model on consumers' attitudes and purchase intentions. This study builds on the integrated framework of Ozsomer and Altaras (2008) to further include the global brand dimensions of local icon value, perceived brand 
globalness, credibility and social responsibility. A survey is conducted in an emerging market i.e. Turkey. All the hypotheses were tested and validated except one hypothesis. The literature review emphasised a positive relationship between perceived brand globalness and perceived CSR efforts of the brand. The findings of this study do not validate this hypothesis because although there is a significant relationship between perceived globalness and perceived CSR of the brand, this relationship is negative. This means that the global brand credibility is a key factor determining the positive perception of its CSR efforts. Therefore, it can be concluded that the perceived globalness of a brand does not necessarily lead to positive perception of its CSR efforts. To generate a positive perception of CSR efforts it is essential that the brand is perceived as credible. The findings show that the credibility of global brands is sourced from the local icon value and perceived brand globalness as suggested by Ozsomer and Altaras (2008). The local icon value has less influence on the credibility of the brand than the perceived brand globalness. Consequently, global companies should give more emphasis to the ties with local culture in emerging markets to increase the credibility of their global brand. According to the findings, there is a positive relationship between the social responsibility and the attitude towards the global brand. As a result, the companies should convey their social responsibility projects to the consumers by using appropriate marketing communications strategies. Nescafé could also get involved in cause related brand alliances (Alcañiz et al., 2010) in order to localise their CSR activities.

In summary, from a theoretical perspective, the results of this study confirm existing theories. However, it provides further insight regarding the relationship between perceived globalness and perceived CSR of the brand. As mentioned above, while credibility is a key factor influencing the perception of global brands' CSR effort, brands' perceived globalness does not seem to positively influence the perception of the brands' CSR efforts.

In this respect, Arnould and Thompson (2005, p. 979) claimed that "people must deal with other peoples' meanings ... at times, perhaps, one can just ignore them" to emphasise the importance of understanding the culture in the market considered by the global firm.

Perceived globalness of the brand is found to positively influence the credibility of the brand. Whereas the local icon value has a positive influence on the credibility of the brand. Brands can capitalise on their perceived globalness and use it as a signal of their credibility in their marketing communications. Global brands need to establish stronger ties with the local culture in Turkey in 
order to increase local icon value and consequently their credibility. Interestingly, this study showed a different result concerning the relationship between global brand perceived globalness and perceived CSR. This relationship, claimed to be positive by previous studies (Ozsomer and Altaras, 2008), is found to be significant but negative. It seems that Nescafé' perceived CSR stems from its credibility as a brand and not from its perceived globalness. Nescafé is perceived as a strong global brand in Turkey but this does not reflect on the perception of their CSR. Hence, practitioners should further understand the reasons why Turkish consumers negatively associate globalness of the brand and their CSR activities and address the issue with appropriate marketing communications strategies such as advertising. In addition, practitioners could also localise their CSR efforts to capitalise on the local icon value of the brand and consequently increase the brand's CSR perception. In this line, Becker-Olsen et al. (2011) claimed that global brands should emphasize their CSR efforts in the markets they operate in to change the consumer's perception about the company. Thus, global brands should highlight their ethically responsible projects through their marketing communications to change consumer perceptions and attitudes (De Mooij, 2018). Nescafé is a well-established brand in Turkey. Krishnan (1996) claimed that it is important to understand the association made by consumers towards brands and this is particularly relevant for mature brands for which consumers may have developed a multitude of associations. Nescafé, and global brands in general, could use the results of this study to reflect on consumer associations of their social responsibility with their brands and appropriately design marketing communications strategies to remove the negative associations of their irresponsibility with their brands.

Finally, this study contributes to consumer culture theory as it identifies tensions between perceived brand globalness and the local icon value. The existing presence of an iconic product (Turkish coffee) in the coffee category makes it difficult for global brands to enhance their credibility signals through local icon value. Although several studies building on consumer culture theory suggest that both local icon value and perceived brand globalness contribute to the credibility of the brand, the presence of a local iconic product creates a tension between these dimensions. Therefore, global brands should consider the influence of iconic local products in their category on the perceptions of the brand's globalness and its associations. 


\section{Limitations and Directions for Future Research}

Despite the contributions that the study provides, it is not without limitations that introduce opportunities for further research. First, the study only examined consumer's relationships with only one brand from a single product category. Future studies can examine consumers' perceptions towards a number of global brands from several product categories with different levels of consumer involvement. In addition, data were collected from one emerging market i.e. Turkey. It seems that the results of this study are in line with previous claims about local icon value and perceived brand globalness which are more important signals of brand credibility in emerging markets than the developed markets (Mandler et al., 2020). Future studies could involve data collection from other emerging markets to confirm these results. This would enhance the generalisability of the results and further validation of the proposed relationships. Another limitation is that the authenticity of the global brand is measured by its local icon value. However, measures for global and foreign authenticity of the brand could also be included in future studies to measure the overall impact of authenticity on global brand credibility (Ozsomer and Altaras, 2008).

Similarly, local brands can be included to use the model for comparing consumer's perceptions about global and local brands. Increasing the number of countries and sample size to test the model could give more strength to the findings. Furthermore, brands could change consumers' perception by forming alliances with other brands to benefit from each other's positive brand associations (Rao et al., 1999). In addition, Lafferty and Goldsmith (2005) argued that the cause-brand alliances have positive influence on the consumer's perception of the brand. Therefore, it is recommended to investigate the impact of cause-brand alliance on the perception of the social responsibility of global brands. 


\section{References}

- Aaker, D. A., \& Joachimsthaler, E. (1999). The lure of global branding. Harvard business review, 77, 137-146.

- Alashban, A. A., Hayes, L. A., Zinkhan, G. M., \& Balazs, A. L. (2002). International brandname standardization/adaptation: Antecedents and consequences. Journal of international marketing, 10(3), 22-48. DOI: 10.1509/jimk.10.3.22.19544.

- Alcañiz, E. B., Cáceres, R. C., \& Pérez, R. C. (2010). Alliances between brands and social causes: The influence of company credibility on social responsibility image. Journal of business ethics, 96(2), 169-186.

- Alden, D. L., Steenkamp, J. B. E., \& Batra, R. (2006). Consumer attitudes toward marketplace globalization: Structure, antecedents and consequences. International Journal of Research in Marketing, 23(3), 227-239. DOI: 10.1016/j.ijresmar.2006.01.010.

- AMA (2014), "Dictionary”, Chicago: The American Marketing Association.

- Arnould, E. J., \& Thompson, C. J. (2005). Consumer culture theory (CCT): Twenty years of research. Journal of consumer research, 31(4), 868-882. DOI: 10.1086/426626.

- Baek, T. H., Kim, J., \& Yu, J. H. (2010). The differential roles of brand credibility and brand prestige in consumer brand choice. Psychology \& Marketing, 27(7), 662-678.

- Baltar, F., \& Brunet, I. (2012). Social research 2.0: virtual snowball sampling method using Facebook. Internet research, 22(1), 57-74.

- Batra, R., Ramaswamy, V., Alden, D. L., Steenkamp, J. B. E., \& Ramachander, S. (2000). Effects of brand local and nonlocal origin on consumer attitudes in developing countries. Journal of consumer psychology,9(2), 83-95. DOI: 10.1207/S15327663JCP0902_3.

- BBC, 2015. "Volkswagen: The scandal explained". [available at: https://www.bbc.co.uk/news/business-34324772]

- Becker-Olsen, K. L., Taylor, C. R., Hill, R. P., \& Yalcinkaya, G. (2011). A cross-cultural examination of corporate social responsibility marketing communications in Mexico and the United States: Strategies for global brands. Journal of International Marketing, 19(2), 30-44. DOI: 10.1509/jimk.19.2.30. 
- Bell, E., Bryman, A., \& Harley, B. (2018). Business research methods. Oxford university press.

- Bengtsson, A., Bardhi, F., \& Venkatraman, M. (2010). How global brands travel with consumers: An examination of the relationship between brand consistency and meaning across national boundaries. International Marketing Review, 27(5), 519-540.

- Blumberg, B. F., Cooper, D. R., \& Schindler, P. S. (2014). Business research methods: McGraw-hill education.

- Buzzell, R. D. (1968). Can you standardize multinational marketing? (pp. 102-113). Reprint Service, Harvard business review.

- Cayla, J., \& Eckhardt, G. M. (2008). Asian brands and the shaping of a transnational imagined community. Journal of Consumer Research,35(2), 216-230. DOI: $10.1086 / 587629$.

- Chin, W. W. (2001). PLS-Graph user's guide. CT Bauer College of Business, University of Houston, USA, 15, 1-16.

- De Jong, M. D., \& van der Meer, M. (2017). How does it fit? Exploring the congruence between organizations and their corporate social responsibility (CSR) activities. Journal of business ethics, 143(1), 71-83.

- De Lima, A. S., \& de Faria, A. R. (2018). A composite beam element with through the thickness capabilities based on global-local superposition. Composite Structures, 189, 728-742.

- De Mooij, M. (2018). Global marketing and advertising: Understanding cultural paradoxes. SAGE Publications Limited.

- De Mooij, M., \& Hofstede, G. (2010). The Hofstede model: Applications to global branding and advertising strategy and research. International Journal of advertising, 29(1), 85-110.

- Deutsche Welle, 2019. “Activists fight deforestation in Turkey's Ida mountains”. [available at https://www.dw.com/en/activists-fight-deforestation-in-turkeys-ida-mountains/a49903433].

- Dimofte, C. V., Johansson, J. K., \& Ronkainen, I. A. (2008). Cognitive and affective reactions of US consumers to global brands. Journal of International Marketing, 16(4), 113-135.

- Dolce Gusto (2012), “The Pleasures of Coffee”, [available at www.dolce-gusto.co.uk]. 
- Douglas, S. P., Craig, C. S., \& Nijssen, E. J. (2001). Executive insights: Integrating branding strategy across markets: Building international brand architecture. Journal of International Marketing, 9(2), 97-114. DOI: 10.1509/jimk.9.2.97.19882.

- Erdem, T., \& Swait, J. (2004). Brand credibility, brand consideration, and choice. Journal of consumer research, 31(1), 191-198.

- Erdem, T., Swait, J., \& Valenzuela, A. (2006). Brands as signals: a cross-country validation study. Journal of marketing, 70(1), 34-49. DOI: 10.1509/jmkg.2006.70.1.34.

- Ferrell, O. C., Harrison, D. E., Ferrell, L., \& Hair, J. F. (2019). Business ethics, corporate social responsibility, and brand attitudes: An exploratory study. Journal of Business Research, 95, 491-501.

- Fornell, C., \& Cha, J. (1994). Advanced Methods of Marketing Research, ed. RP Bagozzi.

- Fornell, C., \& Larcker, D. F. (1981). Evaluating structural equation models with unobservable variables and measurement error. Journal of marketing research, 18(1), 3950. DOI: $10.2307 / 3151312$.

- Ger, G. (1999). Localizing in the global village: Local firms competing in global markets. California Management Review, 41(4), 64-83. DOI: 10.2307/41166010.

- Gray, R. (2002). Local on a global scale. Marketing, 22-22.

- Guo, X., Xiao, G., \& Zhang, F. (2017). Effect of consumer awareness on corporate social responsibility under asymmetric information. Available at SSRN 3039862.

- Hair, J. F., Ringle, C. M., \& Sarstedt, M. (2011). PLS-SEM: Indeed a silver bullet. Journal of Marketing theory and Practice, 19(2), 139-152.

- Hair, J. F., Risher, J. J., Sarstedt, M., \& Ringle, C. M. (2019). When to use and how to report the results of PLS-SEM. European Business Review.

- Hassan, S. S., Craft, S., \& Kortam, W. (2003). Understanding the new bases for global market segmentation. Journal of Consumer Marketing, 20(5), 446-462.

- He, J., \& Wang, C. L. (2017). How global brands incorporating local cultural elements increase consumer purchase likelihood. International Marketing Review. 34 (4), 463-479.

- Henderson, G.R., Iacobucci, D. and Calder, B.J., 1998. Brand diagnostics: Mapping branding effects using consumer associative networks. European Journal of Operational Research, 111(2), pp.306-327.

- Hollis, N., \& Fitch, D. (2009). Is global brand marketing as rewarding as it first appears?. Journal of Sponsorship, 2(3). 
- Holt, D. B., Quelch, J. A., \& Taylor, E. L. (2004). How global brands compete. Harvard business review, 82(9), 68-75.

- Hossain, M. S., Anthony, J. F., Beg, M. N. A., \& Zayed, N. M. (2019). The Consequence of Corporate Social Responsibility on Brand Equity: A Distinctive Empirical Substantiation. Academy of Strategic Management Journal.

- Hsieh, M. H. (2002). Identifying brand image dimensionality and measuring the degree of brand globalization: A cross-national study. Journal of International Marketing, 10(2), 46-67. DOI: 10.1509/jimk.10.2.46.19538.

- Hulland, J. (1999). Use of partial least squares (PLS) in strategic management research: A review of four recent studies. Strategic management journal, 20(2), 195-204.

- Hur, W. M., Kim, H., \& Woo, J. (2014). How CSR leads to corporate brand equity: Mediating mechanisms of corporate brand credibility and reputation. Journal of Business Ethics, 125(1), 75-86. DOI: 10.1007/s10551-013-1910-0

- Hurriyet, (2006). "Yiyin gari dedi, satış beş kat arttı o hálá turşu fabrikasında çalışıyor". [available at https://www.hurriyet.com.tr/kelebek/yiyin-gari-dedi-satis-bes-kat-artti-o-h-1tursu-fabrikasinda-calisiyor-5463962]

- Interbrand (2018), "Best Global Brands 2018 Rankings", [available at https://www.interbrand.com/best-brands/best-global-brands/2018/ranking/].

- Izberk-Bilgin, E. (2008). When Starbucks meets Turkish coffee: Cultural imperialism and islamism as' other' discourses of consumer resistance. ACR North American Advances.

- Johansson, J. K. (2010). Global Marketing Strategy. Wiley International Encyclopedia of Marketing.

- Jones, R. (2005). Finding sources of brand value: Developing a stakeholder model of brand equity. Journal of brand management, 13(1), 10-32.

- Kahve Cini (2010), "Hazır Kahve Markaları", [available at http://www.kahvecini.com/2010/01/hazr-kahve-markalar.html].

- Kapferer, J. N. (2012). The new strategic brand management: Advanced insights and strategic thinking. Kogan page publishers.

- Keane, M., \& Morschett, D. (2017). The Influence of Localised Corporate Social Responsibility and Perceived Brand Localness on Willingness to Buy at a Foreign Grocery Retailer. Marketing ZFP, 39(1), 27-43. DOI: 10.15358/0344-1369-2017-1-27. 
- Keller, K. L., Parameswaran, M. G., \& Jacob, I. (2011). Strategic brand management: Building, measuring, and managing brand equity. Pearson Education India.

- Krishnan, H. S. (1996). Characteristics of memory associations: A consumer-based brand equity perspective. International Journal of research in Marketing, 13(4), 389-405.

- Levitt, T. (1983). The globalization of markets. Harvard Business Review, 61(3), 92-102.

- Liu, Y., Tao, W., \& Tsai, W. H. S. (2017). Global versus local consumer culture positioning in a transitional market: Understanding the influence of consumer nationalism. International Journal of Strategic Communication, 11(4), 344-360.

- Malhotra, N. K., \& Dash, S. (2016). Marketing research: An applied orientation. Pearson.

- Mandler, T., Bartsch, F., \& Han, C. M. (2020). Brand credibility and marketplace globalization: The role of perceived brand globalness and localness. Journal of International Business Studies, 1-32.

- Maneesriwongul, W., \& Dixon, J. K. (2004). Instrument translation process: a methods review. Journal of advanced nursing, 48(2), 175-186.

- Melo, T., \& Galan, J. I. (2011). Effects of corporate social responsibility on brand value. Journal of Brand Management, 18(6), 423-437.

- Mitchell, A. (2002). Few brands can achieve a truly global presence. Marketing Week, February, 7, 32-3.

- Munn, H. L. (1960). Brand perception as related to age, income, and education. Journal of Marketing, 24(3), 29-34.

- Nestle Turkiye, (2019a). NESCAFÉ 3ü1 Arada. Nestle Turkiye.

- Nestle Turkiye, (2019b). Nescafé Planı. Nestle Turkiye.

- Nie, C., \& Wang, T. (2019). How global brands incorporate local cultural elements to improve brand evaluations. International Marketing Review.

- Ozsomer, A. (2012). The interplay between global and local brands: A closer look at perceived brand globalness and local iconness. Journal of International Marketing, 20(2), 72-95. DOI: 10.1509/jim.11.0105.

- Ozsomer, A., \& Altaras, S. (2008). Global brand purchase likelihood: A critical synthesis and an integrated conceptual framework. Journal of International Marketing, 16(4), 1-28. DOI: $10.1509 /$ jimk.16.4.1. 
- Ozsomer, A., \& Simonin, B. L. (2004). Marketing program standardization: A crosscountry exploration. International Journal of Research in Marketing, 21(4), 397-419.

- Ozsomer, A., Batra, R., Chattopadhyay, A., \& Ter Hofstede, F. (2012). A global brand management roadmap. International Journal of Research in Marketing, 1(29), 1-4. DOI: 10.1016/j.ijresmar.2012.01.001.

- Park, C. W., MacInnis, D. J., Priester, J., Eisingerich, A. B., \& Iacobucci, D. (2010). Brand attachment and brand attitude strength: Conceptual and empirical differentiation of two critical brand equity drivers. Journal of marketing, 74(6), 1-17. DOI: 10.1509/jmkg.74.6.1.

- Quelch, J. A., \& Deshpande, R. (Eds.). (2004). The global market: Developing a strategy to manage across borders. John Wiley \& Sons.

- Ramadania, R., Gunawan, S., \& Jamaliah, J. (2014). Country of origin effect and animosity on the attitude and purchase intention of foreign products. Asean Marketing Journal.

- Rao, A. R., Qu, L., \& Ruekert, R. W. (1999). Signaling unobservable product quality through a brand ally. Journal of Marketing Research,36(2), 258-268. DOI: $10.2307 / 3152097$.

- Ratchford, B. T. (1987). New insights about the FCB grid. Journal of advertising research.

- Riefler, P. (2012). Why consumers do (not) like global brands: The role of globalization attitude, GCO and global brand origin. International Journal of Research in Marketing, 29(1), 25-34. DOI: 10.1016/j.ijresmar.2011.11.001.

- Riefler, P. (2020). Local versus global food consumption: the role of brand authenticity. Journal of Consumer Marketing.

- Rosen, B., Boddewyn, J. J., \& Louis, E. A. (1989). US brands abroad: An empirical study of global branding. International Marketing Review, 6(1). DOI: 10.1108/EUM0000000001499.

- Roy, R., \& Chau, R. (2011). Consumer-based brand equity and status-seeking motivation for a global versus local brand. Asia Pacific Journal of Marketing and Logistics, 23(3), 270-284.

- Sabah, (2017). "Volkswagen Türkiye piyasasındaki liderliğini kaybetti". [available at https://www.sabah.com.tr/otomobil/2017/09/10/volkswagen-turkiye-piyasasindakiliderligini-kaybetti] 
- Schuiling, I., \& Kapferer, J. N. (2004). Executive insights: real differences between local and international brands: strategic implications for international marketers. Journal of International Marketing, 12(4), 97-112. DOI: 10.1509/jimk.12.4.97.53217.

- Schuiling, I., \& Lambin, J. J. (2003). Do global brands benefit from a unique worldwide image?. Symphonya. Emerging Issues in Management, (2), 17-26.

- Sharma, R., \& Jain, V. (2019). CSR, Trust, Brand Loyalty and Brand Equity: Empirical Evidences from Sportswear Industry in the NCR Region of India. Metamorphosis, 18(1), $57-67$.

- Srivastava, A., \& Balaji, M. S. (2018). Consumer dispositions toward global brands. Marketing Intelligence \& Planning, 36(6), 618-632.

- Srivastava, A., Dey, D. K., \& Balaji, M. S. (2020). Drivers of brand credibility in consumer evaluation of global brands and domestic brands in an emerging market context. Journal of Product \& Brand Management.

- Steenkamp, J. B. (2017). Global brand strategy: World-wise marketing in the age of branding. Springer.

- Steenkamp, J. B. E. (2019). Global versus local consumer culture: Theory, measurement, and future research directions. Journal of International Marketing, 27(1), 1-19. DOI: $10.1177 / 1069031 X 18811289$.

- Steenkamp, J. B. E., Batra, R., \& Alden, D. L. (2003). How perceived brand globalness creates brand value. Journal of International Business Studies, 34(1), 53-65.

- Strizhakova Y., Coulter R. A., Price L. L. (2008). Branded Products as a Passport to Global Citizenship: Perspectives from Developed and Developing Countries. Journal of International Marketing: Vol. 16 (4), pp. 57-85.

- Sue, V. M., \& Ritter, L. A. (2012). Conducting online surveys. Sage.

- Sweeney, J. C., \& Soutar, G. N. (2001). Consumer perceived value: The development of a multiple item scale. Journal of retailing,77(2), 203-220. DOI: 10.1016/S00224359(01)00041-0.

- Taylor, C. R., \& Okazaki, S. (2015). Do global brands use similar executional styles across cultures? A comparison of US and Japanese television advertising. Journal of Advertising, 44(3), 276-288. DOI: 10.1080/00913367.2014.996306. 
- Teichert Thorsten A. and, Schöntag Katja (2010). Exploring consumer knowledge structures using associative network analysis. Psychology and Marketing, Vol. 27 (4), 369398.

- Tenenhaus, M., Vinzi, V. E., Chatelin, Y. M., \& Lauro, C. (2005). PLS path modeling. Computational statistics \& data analysis, 48(1), 159-205.

- Till, B. D., \& Nowak, L. I. (2000). Toward effective use of cause-related marketing alliances. Journal of Product \& Brand Management. DOI: 10.1108/10610420010351394.

- Torelli, C. J., Özsomer, A., Carvalho, S. W., Keh, H. T., \& Maehle, N. (2012). Brand concepts as representations of human values: do cultural congruity and compatibility between values matter?. Journal of marketing, 76(4), 92-108. DOI: 10.1509/jm.10.0400.

- Torres, A., Bijmolt, T. H., Tribó, J. A., \& Verhoef, P. (2012). Generating global brand equity through corporate social responsibility to key stakeholders. International Journal of Research in Marketing, 29(1), 13-24. DOI: 10.1016/j.jjresmar.2011.10.002.

- Veltmeyer, H. (Ed.). (2017). Globalization and antiglobalization: Dynamics of change in the new world order. Taylor \& Francis. DOI: 10.1177/002088170604400105.

- Vuong, B. N., \& Khanh Giao, H. N. (2020). The impact of perceived brand globalness on consumers' purchase intention and the moderating role of consumer ethnocentrism: An evidence from vietnam. Journal of International Consumer Marketing, 32(1), 47-68.

- Yotova, M. (2018). Ethnographic Heritage as a Branding Strategy: A Case Study of Yogurt in Bulgaria and Japan. Global Economic Review, 47(1), 47-62.

- Wu, S. I., \& Wang, W. H. (2014). Impact of CSR perception on brand image, brand attitude and buying willingness: A study of a global café. International Journal of Marketing Studies, 6(6), 43. 
Appendix 1

SmartPLS output (PLS Algorithm (Path coefficients, $\mathrm{R}^{2}$, item loadings)

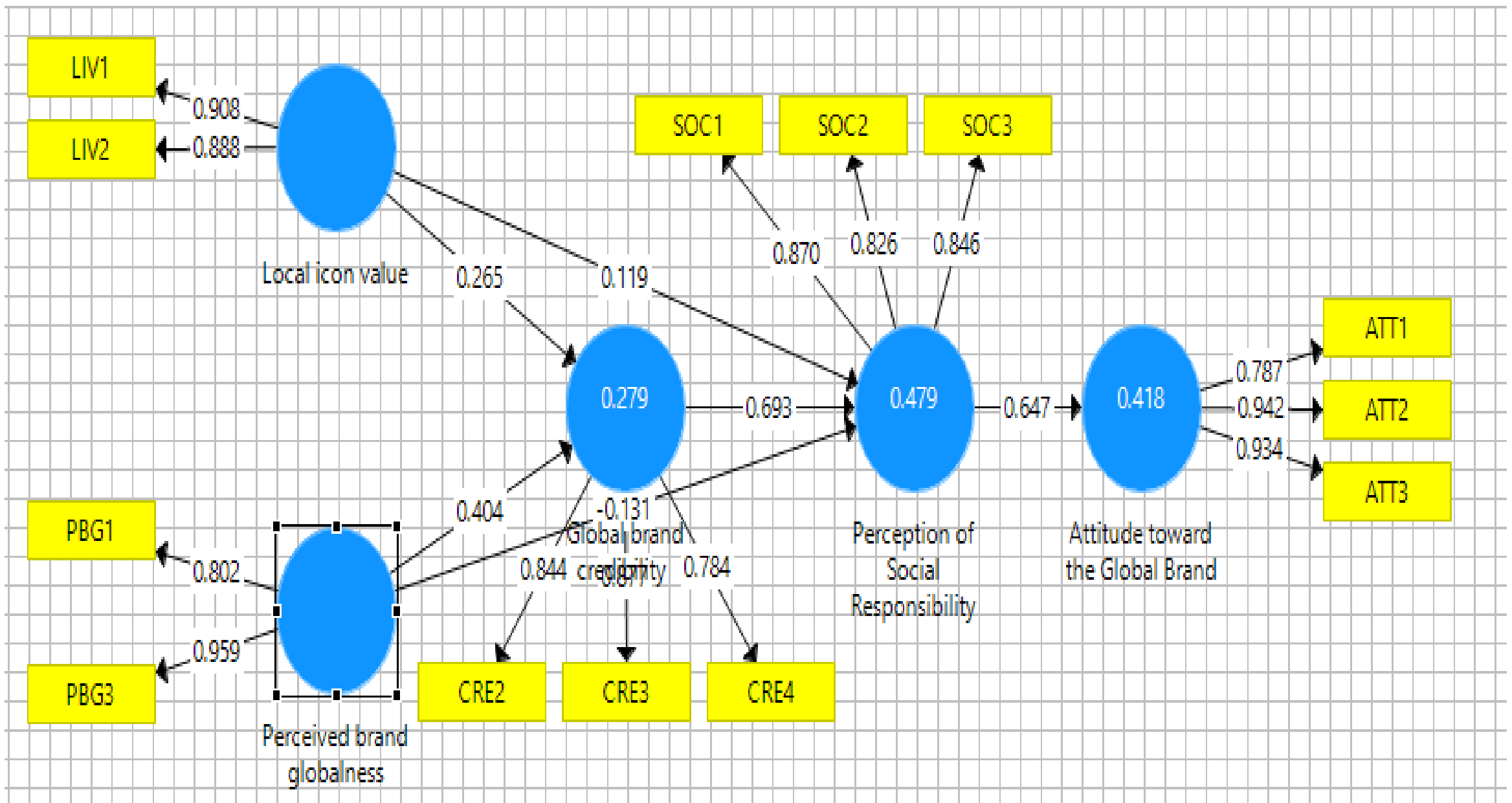




\section{Appendix 2}

SmartPLS output (Bootstrapping, Path coefficients and t-values)

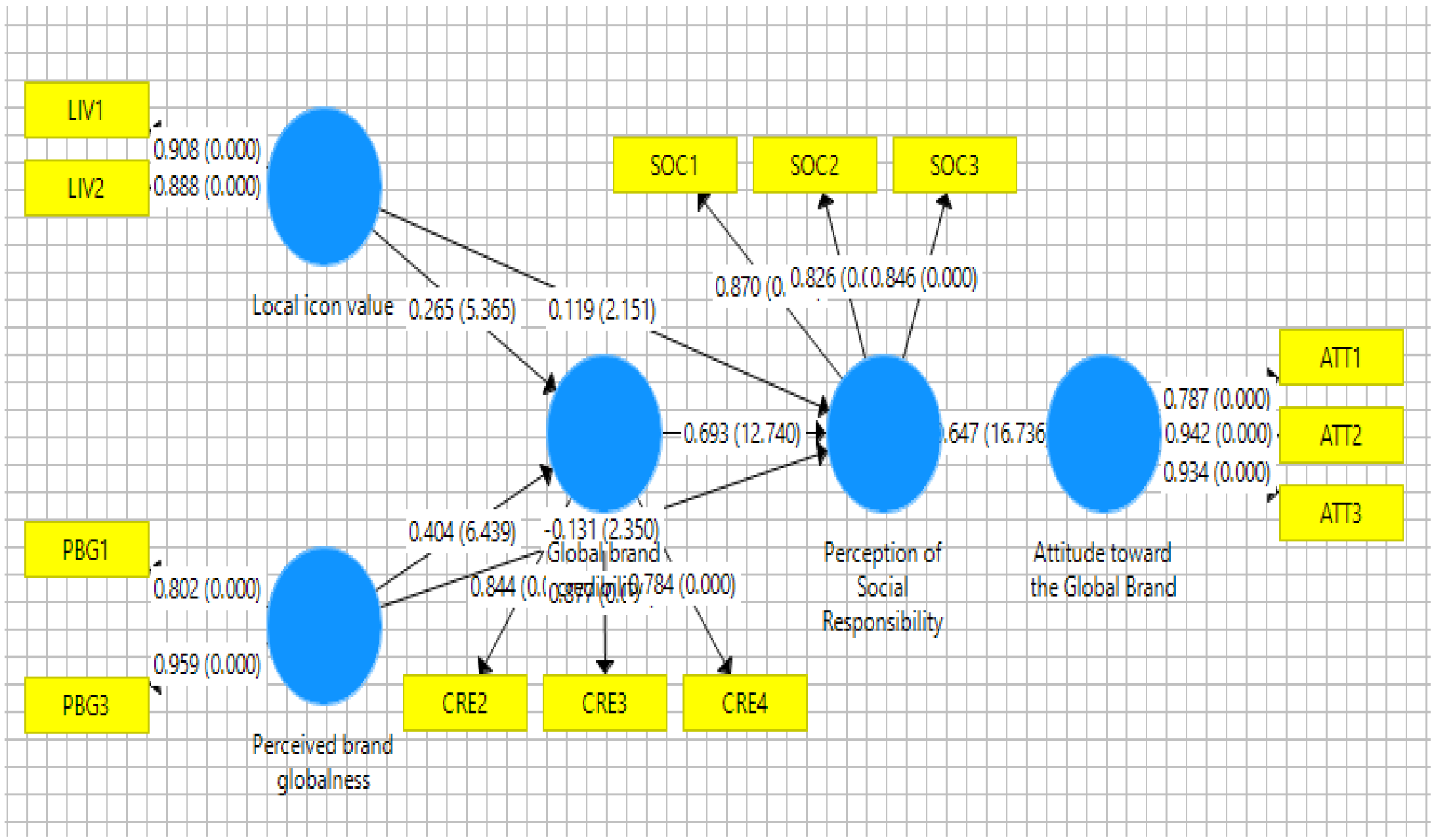




\section{Appendix 3}

\section{Questionnaire items in English and Turkish languages}

\begin{tabular}{|c|c|c|}
\hline Constructs & Items & Source \\
\hline \multirow[t]{3}{*}{ Local Icon Value (LIV) } & $\begin{array}{l}\text { I associate this brand with things that are } \\
\text { Turkish. } \\
\text { Bu markayı Türkiye'ye özgü şeylerle } \\
\text { ilişsilendiriyorum. }\end{array}$ & Steenkamp et al. (2003) \\
\hline & $\begin{array}{l}\text { To me, this brand represents what Turkey is } \\
\text { all about. } \\
\text { Bence bu marka, Türkiye hakkında akla } \\
\text { gelenleri temsil ediyor. }\end{array}$ & Steenkamp et al. (2003) \\
\hline & $\begin{array}{l}\text { To me, this brand is a very good symbol of } \\
\text { Turkey. } \\
\text { Bu markanın, Türkiye'yi yansıtan çok iyi bir } \\
\text { simge olduğunu düşünüyorum. }\end{array}$ & Steenkamp et al. (2003) \\
\hline \multirow[t]{3}{*}{$\begin{array}{l}\text { Perceived Brand Globalness } \\
\text { (PBG) }\end{array}$} & $\begin{array}{l}\text { To me, this is a global brand. } \\
\text { Bence bu global bir marka. }\end{array}$ & Steenkamp et al. (2003) \\
\hline & $\begin{array}{l}\text { I think consumers overseas buy this brand. } \\
\text { Başka ülkelerdeki insanların da bu markayı } \\
\text { satın aldığını düşünüyorum. }\end{array}$ & Steenkamp et al. (2003) \\
\hline & $\begin{array}{l}\text { This brand is sold all over the world. } \\
\text { Bu marka, dünyanın dört bir yanında } \\
\text { satıliyor. }\end{array}$ & Steenkamp et al. (2003) \\
\hline \multirow[t]{4}{*}{$\begin{array}{l}\text { Global Brand Credibility } \\
\text { (CRE) }\end{array}$} & $\begin{array}{l}\text { This brand reminds me of someone who is } \\
\text { competent and knows what he/she's doing. } \\
\text { Bu marka bana, işinin ehli ve ne yaptığını } \\
\text { bilen bir insanı hatırlatıyor. }\end{array}$ & Erdem and Swait (2004) \\
\hline & $\begin{array}{l}\text { This brand has the ability to deliver what it } \\
\text { promises. } \\
\text { Bu marka, söz verdiklerini yerine getirme } \\
\text { yeteneğine sahip. }\end{array}$ & Erdem and Swait (2004) \\
\hline & $\begin{array}{l}\text { This brand has a name you can trust. } \\
\text { Bu markanın güvenilir bir ismi var. }\end{array}$ & Erdem and Swait (2004) \\
\hline & $\begin{array}{l}\text { This brand does not pretend to be something } \\
\text { it isn't. } \\
\text { Bu marka, olmadığı bir şey gibi gözükmeye } \\
\text { çalışmıyor. }\end{array}$ & Erdem and Swait (2004) \\
\hline \multirow[t]{5}{*}{$\begin{array}{l}\text { Global Brand Social } \\
\text { Responsibility (SOC) }\end{array}$} & $\begin{array}{l}\text { This brand cares about the environment. } \\
\text { Bu marka, çevreye önem veriyor. }\end{array}$ & Holt et al. (2004) \\
\hline & $\begin{array}{l}\text { This brand cares about the safety and health } \\
\text { of me and my family. } \\
\text { Bu marka, benim ve ailemin güvenliğine ve } \\
\text { sağlığına önem veriyor. }\end{array}$ & Holt et al. (2004) \\
\hline & $\begin{array}{l}\text { This brand has high ethical standards. } \\
\text { Bu marka, yüksek etik standartlara sahip. }\end{array}$ & Holt et al. (2004) \\
\hline & $\begin{array}{l}\text { This brand treats its employees well. } \\
\text { Bu marka, işçilerine iyi davranıyor. }\end{array}$ & Holt et al. (2004) \\
\hline & $\begin{array}{l}\text { This brand acts like a good neighbour in } \\
\text { Turkey. }\end{array}$ & Holt et al. (2004) \\
\hline
\end{tabular}




\begin{tabular}{|c|c|c|}
\hline & $\begin{array}{l}\text { Bu marka, Türkiye'de iyi bir komşu gibi } \\
\text { hareket ediyor. }\end{array}$ & \\
\hline \multirow[t]{3}{*}{ Global Brand Attitude (ATT) } & $\begin{array}{l}\text { I like this brand. } \\
\text { Bu marka hoșuma gidiyor. }\end{array}$ & Batra et al. (2000) \\
\hline & $\begin{array}{l}\text { I have a positive opinion about this brand. } \\
\text { Bu marka hakkında olumlu bir görüşe } \\
\text { sahibim. }\end{array}$ & Batra et al. (2000) \\
\hline & $\begin{array}{l}\text { I would recommend this brand to others. } \\
\text { Bu markayı başkalarına önerebilirim. }\end{array}$ & Park et al. (2010) \\
\hline Demographic Questions & Options (Turkish in brackets) & \\
\hline \multirow{6}{*}{$\begin{array}{l}\text { What is your age range? } \\
\text { (Yaş grubunuz) }\end{array}$} & $16-24$ & \\
\hline & $25-34$ & \\
\hline & $35-44$ & \\
\hline & $45-54$ & \\
\hline & $55-64$ & \\
\hline & 65 and over (65 ve üstï) & \\
\hline \multirow{2}{*}{$\begin{array}{l}\text { Your gender } \\
\text { (Cinsiyetiniz) }\end{array}$} & Male (Erkek) & \\
\hline & Female (Kadın) & \\
\hline \multirow{5}{*}{$\begin{array}{l}\text { What is your educational } \\
\text { background? } \\
\text { (Eğitim durumunuz) }\end{array}$} & Primary school (İlköğretim) & \\
\hline & High school (Lise) & \\
\hline & Bachelor's degree - University (Üniversite) & \\
\hline & Master's degree (Yüksek Lisans) & \\
\hline & Ph.D. (Doktora) & \\
\hline \multirow{5}{*}{$\begin{array}{l}\text { What is your occupation? } \\
\text { (İş durumunuz) }\end{array}$} & Student (Öğrenci) & \\
\hline & Employee - Worker (Çalışan - İşçi) & \\
\hline & $\begin{array}{l}\text { Employer - Entrepreneur (İşveren - } \\
\text { Girişimci) }\end{array}$ & \\
\hline & Retired (Emekli) & \\
\hline & Unemployed (İşsiz) & \\
\hline
\end{tabular}

